\title{
Fairly Good
}

National Cancer Institute

\section{Source}

National Cancer Institute. Fairly Good. NCI Thesaurus. Code C121634.

An indication that something has a moderate degree of quality, value or worth. 